\title{
Single and Multiple Impact Ignition of New and Aged High Explosives in the Steven Impact Test
}

\author{
S.K. Chidester \\ C.M. Tarver \\ A.H. DePiero \\ R.G. Garza
}

This paper was prepared for submittal to the

11th APS Topical Conference on Shock Compression

of Condensed Matter

Snowbird, UT

June 27-July 2, 1999

June 1999

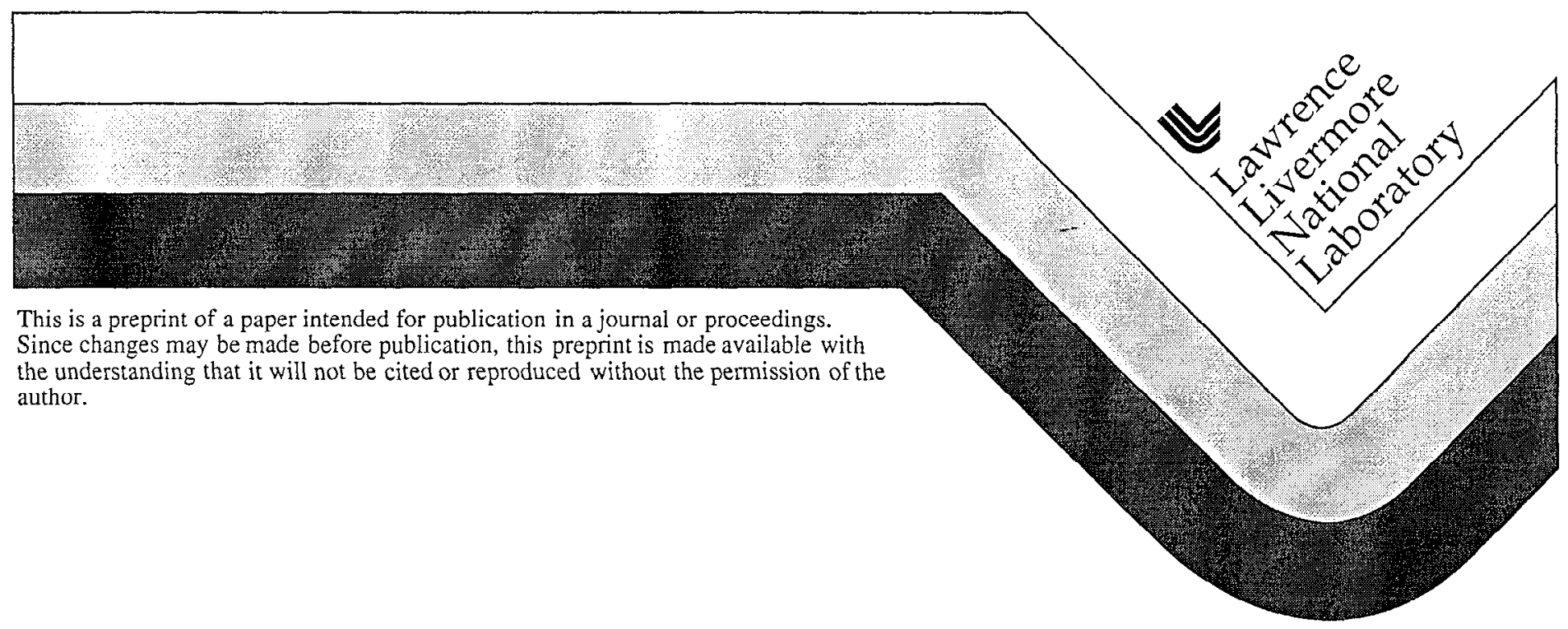




\section{DISCLAIMER}

This document was prepared as an account of work sponsored by an agency of the United States Government. Neither the United States Government nor the University of California nor any of their employees, makes any warranty, express or implied, or assumes any legal liability or responsibility for the accuracy, completeness, or usefulness of any information, apparatus, product, or process

disclosed, or represents that its use would not infringe privately owned rights. Reference herein to any specific commercial product, process, or service by trade name, trademark, manufacturer, or otherwise, does not necessarily constitute or imply its endorsement, recommendation, or favoring by the United States Government or the University of California. The views and opinions of authors expressed herein do not necessarily state or reflect those of the United States Government or the University of California, and shall not be used for advertising or product endorsement purposes. 


\title{
SINGLE AND MULTIPLE IMPACT IGNITION OF NEW AND AGED HIGH EXPLOSIVES IN THE STEVEN IMPACT TEST
}

\author{
S. K. Chidester, C. M. Tarver, A. H. DePiero and R. G. Garza \\ Lawrence Livermore National Laboratory, \\ P.O. Box 808, L-125, Livermore, CA 94551
}

\begin{abstract}
Threshold impact velocities for ignition of exothermic reaction were determined for several new and aged HMX-based solid high explosives using three types of projectiles in the Steven Test. Multiple impact threshold velocities were found to be approximately $10 \%$ lower in damaged charges that did not react in one or more prior impacts. Projectiles with protrusions that concentrate the friction work in a small volume of explosive reduced the threshold velocities by approximately $30 \%$. Flat projectiles required nearly twice as high velocities for ignition as rounded projectiles. Blast overpressure gauges were used for both pristine and damaged charges to quantitatively measure reaction violence. Reactive flow calculations of single and multiple impacts with various projectiles suggest that the ignition rates double in damaged charges.
\end{abstract}

\section{INTRODUCTION}

With safety issues playing a dominate role in present-day energetic materials technology, concern is increasing about the relative safety of solid high explosives exposed to various impact scenarios during handling, shipping, and storage throughout their lifetimes. The Steven Test (1-4) was developed to determine relative impact sensitivity in a reproducible manner that can be modeled using reactive flow hydrodynamic computer codes. The resulting reactive flow models can then be used to predict the impact sensitivity of explosive charges in scenarios that are too expensive, too time prohibitive, or impossible to test directly.

\section{EXPERIMENTAL}

The experimental geometry of the Steven impact test target and three projectiles are shown in Fig. 1. The three projectiles are steel cylinders with impact surfaces of different spherical radii: $30.05,6.35$, and $203.2 \mathrm{~mm}$, respectfully. Projectiles \#2 and \#3 (1.6 $\mathrm{kg}$ ) weigh more than Projectile \#1 (1.2 kg) to test a projectile mass intermediate between Projectile \# 1 and the $2 \mathrm{~kg}$ mass used by Idar et al.(5) One of these three projectiles is accelerated by a gas gun into 110 $\mathrm{mm}$ diameter by $12.85 \mathrm{~mm}$ thick explosive charges confined by $3.175 \mathrm{~mm}$ thick steel plates on the impact face and $19.05 \mathrm{~mm}$ thick steel plates on the rear surface. The explosive charge is press fit into a Teflon retaining ring, thus eliminating air gaps and insuring full confinement. Testing results from Six HMX-based explosives, the five discussed previously (3) and EDC37 (91 wt \% HMX, $8 \mathrm{wt} \% \mathrm{~K}-10$, and $1 \mathrm{wt} \%$ Nitrocellulose), are presented in this paper.

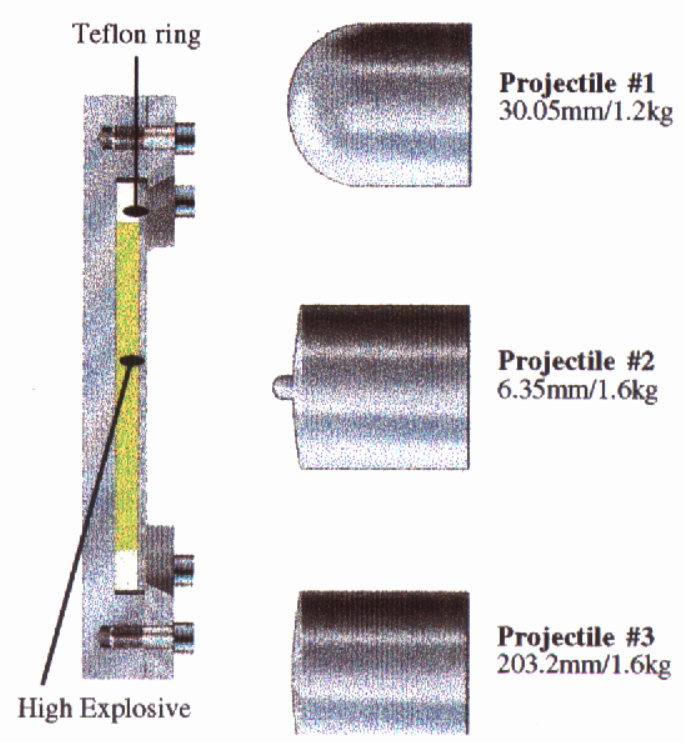

FIGURE 1. Geometry of the target and 3 projectiles 
TABLE 1. Summary of Intentional Detonation Experiments

\begin{tabular}{|c|c|c|c|}
\hline $\begin{array}{l}\text { High } \\
\text { Fxplosive } \\
\text { type }\end{array}$ & $\begin{array}{l}\text { Density } \\
\left(\mathrm{g} / \mathrm{cm}^{3}\right)\end{array}$ & $\begin{array}{c}\operatorname{mass} \\
(\mathrm{g})\end{array}$ & $\begin{array}{c}\text { Average } \\
\text { overpressure } \\
\text { (psi) }\end{array}$ \\
\hline 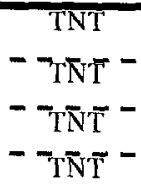 & $\begin{array}{l}1.635 \\
1.635 \\
1.635 \\
1.635\end{array}$ & 175 & $\begin{aligned} & 14.30 \\
- & 18 . \overline{03}--- \\
- & \overline{11} . \overline{86} \sigma^{-}- \\
- & \overline{11} . \overline{93}---\end{aligned}$ \\
\hline $\begin{array}{l}\text { PBX 9501 } \\
\text { PBX9501 }\end{array}$ & $\begin{array}{l}1.830 \\
1.829^{-}\end{array}$ & $\begin{array}{l}227 \\
227\end{array}$ & $\begin{array}{r}15.25 \\
-15 . \overline{1} 0^{-}\end{array}$ \\
\hline
\end{tabular}

Several targets were initiated with detonators to check the diagnostics and to establish a blast overpressure database, which is listed in Table 1 , to compare the measured violence from impact reactions $(2,3)$ to actual detonation overpressures.

The single impact test data for Projectile \#1 is presented in Table 2. Somc of the testing results indicate a need for additional testing. Namely, the 230 month stockpile aged PBX 9501 data set of four must be increased to get an impact velocity where there is not a $\mathrm{HE}$ reaction. Also, large testing uncertainties, such as that for EDC37, can be reduced with additional testing. Tables 2-5 all include several explosive densities and stockpile ages, but there are also other differences that need to be quantified. These differences include but are not limited to: HMX particle size; Estane binder molecular weight; nitroplasticizer content in some binders; RDX content; and lot to lot variations.

The footnote in the third column of Table 2 indicates that the LX-14 was not aged in the stockpilc. However, the explosive was actually aged in a more sever environment including larger diurnal temperature changes, more moisture, higher temperatures, and higher oxygen concentrations.

Multiple impacts become important in accident scenarios when an assembly containing explosives is hit and damaged but without causing an explosive reaction. In this case, the main questions to be asked are: "Is the explosive now more sensitive and, if so, can we quantify the increased sensitivity." The answer is obtained by conducting testing such as presented in Table 3. As a typical example, the threshold velocity for PBX 9501 was reduced from 46.5 to $41.3 \mathrm{~m} / \mathrm{s}$ when previously damaged.

Model validation is contingent on testing presented in Tables 4 and 5 . This testing shows that the projectile's impact surface radius has a significantly large effect on the explosive threshold velocity. Projectile \#3 (nearly flat impact surface) has an approximately $100 \%$ higher threshold velocity than that of Projectile \#2 (protrusion on impact surface).

TABLE 2. Summary of Single Impact Tested Thresholds for Projectile \#1

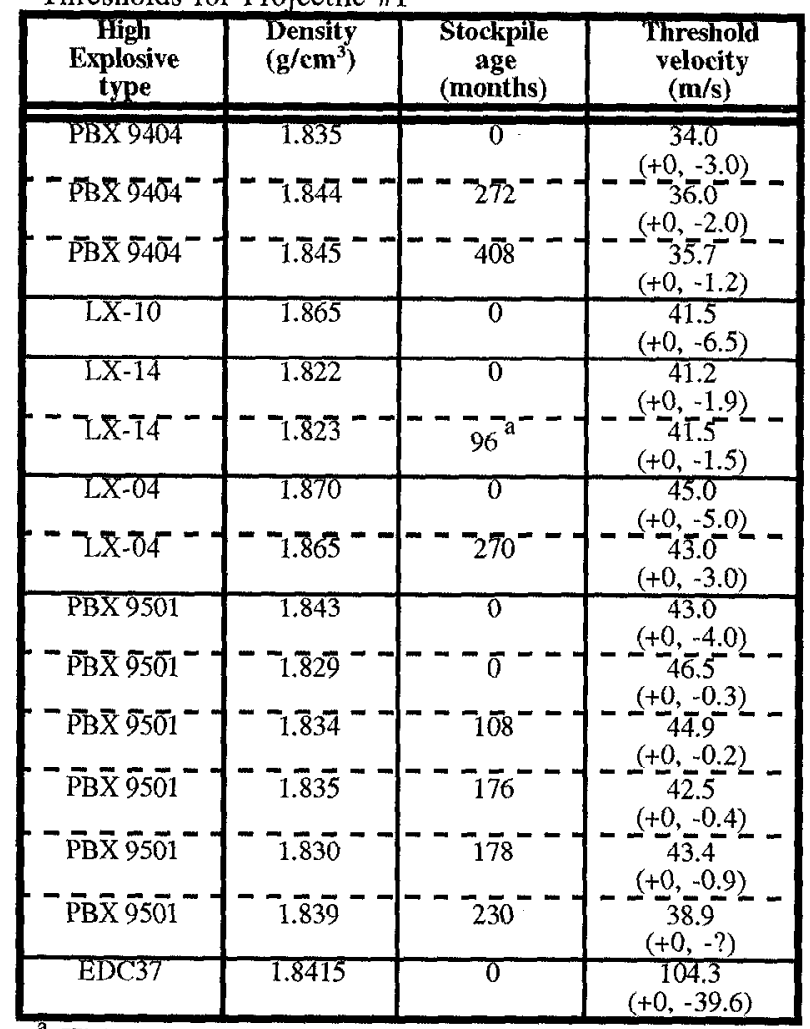

This set of four LX-14 samples were not aged in the stockpile.

TABLE 3. Multiple Impacts Summary of Tested Thresholds for Projectile \#1

\begin{tabular}{|c|c|c|c|}
\hline $\begin{array}{c}\text { High } \\
\text { Explosive } \\
\text { type }\end{array}$ & $\begin{array}{l}\text { Density } \\
\left(\mathrm{g} / \mathrm{cm}^{3}\right)\end{array}$ & $\begin{array}{c}\text { Stockpile } \\
\text { age } \\
\text { (months) }\end{array}$ & $\begin{array}{c}\text { Tested } \\
\text { threshold } \\
\text { velocity }(\mathrm{m} / \mathrm{s})\end{array}$ \\
\hline $\begin{array}{c}\mathrm{PBX} 9404 \\
-\overline{\mathrm{PBX}} \overline{9404}-\end{array}$ & $\begin{array}{r}1.835 \\
-1 . \overline{84} \overline{4}\end{array}$ & $\overline{0}$ & $\begin{array}{c}30.9 \\
(+0,-0.9) \\
3 \overline{1} .4 \\
(+0,-0.7)\end{array}$ \\
\hline LX-10 & 1.865 & 0 & $\begin{array}{c}36.8 \\
(+0,-0.6)\end{array}$ \\
\hline CX-04 & 1.865 & 270 & $\frac{10.2}{(+0,-0.2)}$ \\
\hline $\begin{array}{l}\text { PBX9501 } \\
-\overline{P B X} 9501-\end{array}$ & $\begin{array}{r}1.829 \\
--1.830\end{array}$ & $\pi$ & $\begin{array}{c}41.3 \\
-(+0,-0.4) \\
39.1 \\
(+0,-0.5)\end{array}$ \\
\hline EDC37 & 1.8415 & 0 & $\begin{array}{c}126.1 \\
(+0,-35.9)\end{array}$ \\
\hline
\end{tabular}


TABLE 4. Summary of Single Impact Tested Thresholds for Projectile \#2

\begin{tabular}{|c|c|c|c|}
\hline $\begin{array}{c}\text { High } \\
\text { Explosive } \\
\text { type }\end{array}$ & $\begin{array}{l}\text { Density } \\
\left(\mathrm{g} / \mathrm{cm}^{3}\right)\end{array}$ & $\begin{array}{c}\text { Stockpile } \\
\text { age } \\
\text { (months) }\end{array}$ & $\begin{array}{c}\text { Tested } \\
\text { threshold } \\
\text { velocity }(\mathbf{m} / \mathbf{s})\end{array}$ \\
\hline $\mathrm{LX}-14$ & 1.822 & $\overline{0}$ & $\begin{array}{r}2 \\
(+0,\end{array}$ \\
\hline $\begin{array}{c}\text { LX-04 } \\
- \text { LX-04- }\end{array}$ & $\begin{array}{l}1.870 \\
1.867\end{array}$ & 0 & 30.7 \\
\hline $\begin{array}{r}\text { PBX9501 } \\
\text { PBX950I }\end{array}$ & $\begin{array}{l}1.830 \\
1.8 \overline{3} 5\end{array}$ & 0 & $(+0,-0.2)$ \\
\hline
\end{tabular}

TABLE 5. Summary of Single Impact Tested Thresholds for Projectile \#3

\begin{tabular}{|c|c|c|c|}
\hline $\begin{array}{c}\text { High } \\
\text { Explosive } \\
\text { type }\end{array}$ & $\begin{array}{l}\text { Density } \\
\left(\mathrm{g} / \mathrm{cm}^{3}\right)\end{array}$ & $\begin{array}{c}\text { Stockpile } \\
\text { age } \\
\text { (months) }\end{array}$ & $\begin{array}{c}\text { Tested } \\
\text { threshold } \\
\text { velocity }(\mathbf{m} / \mathbf{s})\end{array}$ \\
\hline $\begin{array}{c}\mathrm{LX-04} \\
-\mathrm{LX}-04^{-}\end{array}$ & 1.870 & 0 & $\begin{array}{c}61.5 \\
-(+0,-0.8) \\
61.9 \\
(+0,-1.2)\end{array}$ \\
\hline
\end{tabular}

\section{REACTIVE FLOW MODELING RESULTS}

Ignition and Growth reactive flow model parameters for LX-10, PBX 9404, PBX 9501, LX04 , and LX-14 were calibrated to the experimental threshold velocities measured using the Projectile \#1 by Chidester et al.(3) These models also correctly calculated the pressure histories in the impacted explosive target measured by internal pressure gauges and the times to violent reaction measured by fast framing cameras.(3) The calibrated model for LX-04 was then used to predict the reaction threshold velocity curves for LX-04 for the comparison shown in Fig. 2 with the test data for Projectiles \#2 and \#3. After the predictions were published,(4) Steven testing was conducted to validate the model. The correct trend was calculated for the LX-04 experimental threshold velocities for Projectiles \#2 and \#3 listed in Tables 4 and 5, but the agreement is not yet quantitativc. Each projectile's geometry effects the explosive target in a unique way. For example, the protruding nose of Projectile \#2 concentrates the frictional work in a much smaller volume of the impacted explosive charge, producing more damage and a greater amount of heated explosive in that small region than do the more rounded projectiles. Similarly, for the multiple impact results listed in Table 3, the damage done by the impacts proceeding the one which finally causes violent reaction produce a greater degree of porosity and more potential hot spot reaction sites in the damaged explosive targets. The measured threshold velocity decreases approximately $10 \%$ for the previously damaged targets and approximately $30 \%$ for Projectile \#2 compared to those for Projectile \#1. Increasing the amount of localized work and frictional heating by using a protruding nose appears to be more effective than creating lesser amounts of damage over a larger volume of explosive material.

To account for the increased ignition rates in the multiple Projectile \#1 impacts and the single Projectile \#2 impact scenarios, the Ignition rate coefficient was increased from the value of $1000 \mu \mathrm{s}^{-1}$ used previously until the calculated threshold velocities matched with the experimental values. Tables 6 and 7 list the values obtained for the Ignition coefficient $I$ for the various HMX-based explosives. The remaining equation of state and reaction rate parameters were the same as those reported by Chidester et al.(3) Increases in ignition rates of slightly less than factors of 2 were necessary to account for the increased sensitivity of the damaged targets, and increases slightly greater than factors of 2 were needed for the increased friction work done by Projectile \#2. This implies that the nose of Projectile \#2 or previous damage produces twice as reacting surface area in the explosive targets.

TABLE 6. Ignition Coefficients and Calculated Results for Multiple Impacts Listed in Table 3

\begin{tabular}{|c|c|c|c|}
\hline $\begin{array}{c}\text { High } \\
\text { Explosive } \\
\text { type }\end{array}$ & $\begin{array}{c}\text { Tomition } \\
\text { coefficient I } \\
\left(\mu \mathbf{s}^{\mathbf{1}}\right)\end{array}$ & $\begin{array}{c}\text { Cacuated } \\
\text { threshold } \\
\text { velocity }(\mathbf{m} / \mathbf{s})\end{array}$ & $\begin{array}{c}\text { Cacnated } \\
\text { time to } \\
\text { reaction }(\mu \mathbf{s})\end{array}$ \\
\hline PBX 9404 & 1990 & $31-32$ & 540 \\
\hline LX-10 & 1930 & $36-37$ & 276 \\
\hline LX-04 & 1600 & $40-41$ & 274 \\
\hline PBX9501 & 1900 & $39-40$ & 534 \\
\hline
\end{tabular}

TABLE 7. Ignition Coefficients and Calculated Results for the Single Impacts Listed in Table 4

\begin{tabular}{|c|c|c|c|}
\hline $\begin{array}{c}\text { High } \\
\text { Explosive } \\
\text { type }\end{array}$ & $\begin{array}{c}\text { Ignition } \\
\text { coefficient I } \\
\left(\mu \mathbf{s}^{-\mathbf{1}}\right)\end{array}$ & $\begin{array}{c}\text { Calculated } \\
\text { threshold } \\
\text { velocity }(\mathbf{m} / \mathbf{s})\end{array}$ & $\begin{array}{c}\text { Calculated } \\
\text { time to } \\
\text { reaction }(\mu \mathrm{s})\end{array}$ \\
\hline $\mathrm{LX}-10$ & 2125 & $24-25$ & 390 \\
\hline $\mathrm{LX}-04$ & 2050 & $30-31$ & 624 \\
\hline PBX9501 & 2050 & $28-29$ & 294 \\
\hline
\end{tabular}




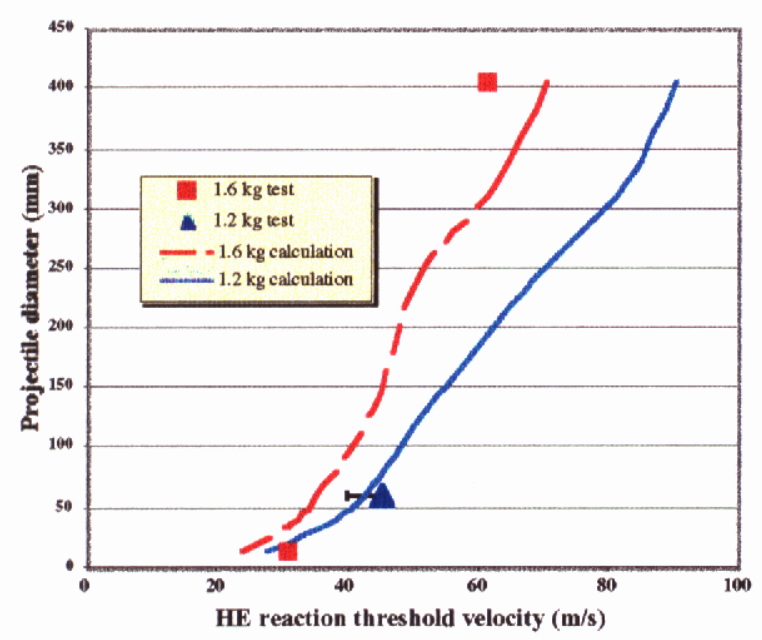

Figure 2. Reaction curves and test data for LX-04

\section{SUMMARY}

The changes in high explosive safety caused by chemical aging, physical aging, or mechanical damage must be quantified. Testing and analysis that is presented here and by others (5-7) needs to be continued to build the required testing data base and develop predictive tools. For example, Steven impact testing of pre-heated and pre-cooled high explosive targets and targets pressed to various initial densities is planned to determine the effects of initial temperature and initial porosity on the threshold for and violence of explosive reactions. Analysis of the testing helps to determine the reaction mechanisms and provides tools to accurately predict the response of an accident scenario. Since not all possible accident scenarios can be tested, reliable reactive flow models based on data from well-instrumented and reproducible experiments are necessary. Additional work is required to refine the calculations presented in Fig. 2 by further parameter studies and calculating other tested geometries such as those published by Idar et al.(5) with the same established coefficients. When normalized to experimental data, reactive flow models such as the phenomenological Ignition and Growth model developed in this paper can predict changes in impact sensitivity over certain ranges of impact geometry and explosive properties.

However, to develop truly predictive reactive flow models that can reliably simulate a wide variety of impact scenarios, a great deal of experimental and theoretical work must be done on the fundamental physical and chemical processes which determine the ignition rates of that first small amount of explosive that starts the exothermic process. The various postulated processes that may heat the explosive to thermal decomposition, such as friction, shear, void collapse, etc., have to be isolated and quantitatively measured in well diagnosed experiments. Then it must be determined experimentally and theoretically which process (or processes) is responsible for ignition under each set of conditions produced by various impact scenarios. Only then can reliable predictions of the impact safety and useful lifetimes of high explosives be made.

\section{ACKNOWLEDGMENTS}

The authors would like to thank Cynthia Nitta, Roger Logan, Deanne Idar, and Stephen Wortley for their interest. This work was performed under the auspices of the U.S. Department of Energy by Lawrence Livermore National Laboratory (contract no.W-7405-ENG-48).

\section{REFERENCES}

1.Chidester, S. K., Green, L. G., and Lee, C. G., Tenth International Detonation Symposium, ONR 33395 12, Boston, MA, 1993, pp. 785-792.

2.Chidester, S. K., Tarver, C. M., and Lee, C. G. in Shock Compression of Condensed Matter-1997, Schmidt, S. C., Dandekar, D. P., and Forbes, J. W., eds., AIP Conference Proceedings 429, AIP Press, New York, 1998, pp. 707-710.

3. Chidester, S. K., Tarver, C. M., and Garza, C. G., Eleventh International Detonation Symposium, Aspen. CO, 1998, in press.

4. DePiero, A. H., Fifth International LS-DYNA Users Conference, 1998, Section M, \#2.

5. Idar, D. J., Lucht, R. A., Straight, J. W., Scammon, R. J., Browning, R. V., Middleditch, J., Dienes, J. K., Skidmore, C. B., and Buntain, G. A., Eleventh International Detonation Symposium, Àspen, CO, 1998 , in press.

6. Scammon, R. J., Browning, R. V., Middleditch, J., Dienes, J. K., Haberman, K. S., and Bennett, J.' G., Eleventh International Detonation Symposium, Aspen, CO, 1998, in press.

7. Browning, R. V. in Shock Compression of Condensed Matter-1995, Schmidt, S. C. and Tao, W. C., eds., AIP Press, New York, 1996, p. 405-408. 